were transferred to the new Ministry of Fuel and Power. Having completed the work for the Government that he had undertaken to do, he resigned his position a few weeks ago.

\section{Bicentenary of Dr. Edmund Cartwright}

APRIL 24 marks the bicentenary of the birth of Rev. Edmund Cartwright, who by his invention of the power-worked loom made a notable contribution to the progress of cotton manufacture. A descendant of a family long established at Marnham, Nottinghamshire, he was educated at Wakefield Grammar School and University College, Oxford, took holy orders, and married a lady of wealth. His first appointment was to the perpetual curacy of Brampton, Yorkshire, but in 1779 he was made rector of Goadby Marwood, Leicestershire. His interests at this time were mainly connected with agriculture and poetry, but a visit to Matlock in 1784 changed the current of his life. At that time the work of Paul, Hargreaves, Arkwright and Crompton had placed the spinners far ahead of the weavers, and at Matlock, Cartwright was present at a conversation when mechanical weaving was declared an impossibility. His latent powers of invention were aroused, and at Goadby Marwood, with the assistance of the local craftsmen, he made a crude loom in which the necessary movements were all made by mechanical power.

In the following year, 1785, Cartwright secured the first of his three patents in connexion with weaving. He next opened a weaving mill at Doncaster, and there made inventions in wool combing and another for rope-making. This last, an outstanding and basic invention, was the 'Cordelier', which soon became part of everyday practice. Unfortunately, the mill was not a financial success, and by 1793 Cartwright had spent a fortune of $£ 30,000$ and had got into debt. Recording his feelings in a stoical sonnet, he left Doncaster for London and about 1800 entered the service of the Duke of Bedford at Woburn, and much of his later life was devoted to agriculture. His looms, much improved by other mechanics, gradually came into use, and in 1809 the Government was prevailed upon to award him a sum of $£ 10,000$, a part of which Cartwright used to buy a farm at Hollander, between Sevenoaks and Tonbridge. His death took place at Hastings on October 30, 1823, by which time there were probably more than twenty thousand power looms in England and Scotland. $\mathrm{He}$ is buried at Battle, Sussex, where a tablet to him was placed in the church.

\section{William Wallace (1768-1843)}

A Century ago, on April 28, 1843, William Wallace, the Scottish mathematician and astronomer, died at the age of seventy-four. Born at Dysart, on September 23, 1768, Wallace began life as a bookbinder's apprentice, but by private study and the assistance of Robison, Playfair and others gained a sound knowledge of mathematics, and at the age of twenty-six became an assistant master in Perth Academy. Nine years later, in 1803, he became an instructor at the Royal Military College, then housed at Great Marlow. In 1819 he was chosen to succeed Leslie as professor of mathematics at the University of Edinburgh, and he held this post until seventy years of age. On retirement he was awarded a Civil List pension of $£ 300$. He had many interests, wrote much for the "Encyclopædia Britannica", contributed to the Royal Astronomical Society and other bodies, and it was largely through his efforts that the small private observatory on Calton Hill, Edinburgh, was improved, the observatory being taken over by the Crown in 1834 when Thomas Henderson became the first Astronomer Royal for Scotland.

\section{Society of Fellows Foundation at Harvard}

IT is announced in the New York Herald Tribune that the Society of Fellows Foundation at Harvard University, which was established by the late Dr. A. Lawrence Lowell, president of Harvard from 1909 until 1933, was also endowed by him with a fund of $2,000,000$ dollars. Dr. Lowell made the gift anonymously, directing that his name was not to be divulged until after his death, when the fund was to be named after his wife, Anna Parker Lowell. By the terms of the Foundation, the principal of the fund is kept intact and the income used to enable a small number of men selected for their promise of making notable contributions to knowledge to devote their whole time to productive scholarship. The selected men are known as 'junior fellows' and receive tuition and accommodation privileges and 1,250-1,500 dollars a year. By this announcement, it is known that Harvard is indebted to Dr. Lowell not only for much of its present reputation and indirectly for its separate colleges, but also for its well-known fellowships. Dr. Lowell died on January 6, aged eighty-six (see Nature, Feb. 13, p. 190).

\section{Rock Paintings in Southern Rhodesia}

In a paper before the Rhodesia Scientific Association, Mr. L. Cripps has again directed attention to the rock-shelter paintings of Southern Rhodesia (Proc. Rhodesia Sci. Assoc., 39 ; 1942). There is still much to be done, and soon, if these paintings are to be preserved, or at least properly studied before their almost inevitable destruction follows on the more intensive opening up of the country. Incidentally, Mr. Cripps mentions the well-known site in the N'danga-Victoria district, whore the so-called Egyptian figures occur. Dr. Impey, who first described the site, likened them to certain predynastic Egyptian paintings, and this equation is now assumed by a number of prehistorians. Attention might be directed, however, to some rock-shelter paintings from Ido in the Fezzan district south of Tripoli, North Africa, where very similar painted figures occur. They are reproduced (Plate lxxxi) in Leo Frobenius's recent publication "Ekade Ektob, die Felsbilder Fezzans", 1937. Perhaps for the present it would be wiser to equate the N'danga paintings with counterparts in North Africa rather than to suggest that they owe their origin to predynastic Egyptians penetrating as immigrants southwards to Rhodesia.

\section{Seismological Tables}

A SET of seismological tables by Dr. H. Jeffreys and Dr. K. E. Bullen dated 1940 and published by the British Association for the Advancement of Science from its offices at Burlington House, London, $W .1$, has just been received. The tables are published with the assistance of a grant from the Gray Milne Trust. They have all been published previously by the Royal Astronomical Society and are reproduced in the booklet above mentioned in collected form. 